July 2008

IMF Country Report No.08/252

\title{
Finland: Report on the Observance of Standards and Codes- FATF Recommendations for Anti-Money Laundering and Combating the Financing of Terrorism
}

This Report on the Observance of Standards and Codes on the FATF Recommendations for Anti-Money Laundering and Combating the Financing of Terrorism for Finland was prepared by the Financial Action Task Force on Money Laundering (FATF), using the assessment methodology adopted by the FATF in February 2004 and endorsed by the Executive Board of the IMF in March 2004. The views expressed in this document, as well as in the full assessment report, are those of the FATF and do not necessarily reflect the views of the Government of Finland or the Executive Board of the IMF.

A copy of the full assessment report can be found on the website of the FATF at http://www.fatfgafi.org

Copies of this report are available to the public from

International Monetary Fund $\bullet$ Publication Services

700 19th Street, N.W. • Washington, D.C. 20431

Telephone: (202) $6237430 \bullet$ Telefax: (202) 6237201

E-mail: publications@imf.org • Internet: http://www.imf.org

Price: $\$ 18.00$ a copy

International Monetary Fund

Washington, D.C. 



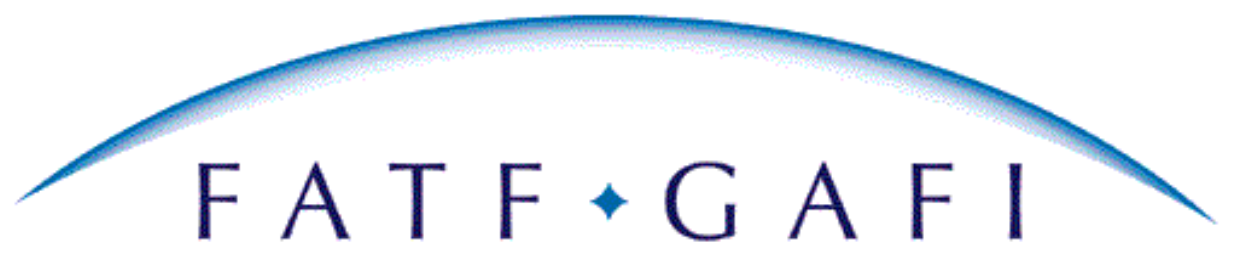

Financial Action Task Force

\section{Groupe d'action financière}

\section{FINLAND}

Report on Observance of Standards and Codes

FATF Recommendations for Anti-Money Laundering and Combating the Financing of Terrorism 
๑ 2007 FATF/OECD. All rights reserved. 


\section{REPORT ON OBSERVANCE OF STANDARDS AND CODES}

\section{FATF RECOMMENDATIONS FOR ANTI-MONEY LAUNDERING AND COMBATING THE FINANCING OF TERRORISM}

\section{FINLAND}

\section{Background Information}

1. This Report on the Observance of Standards and Codes for the FATF $40+9$ Recommendations was prepared by the Financial Action Task Force. The report provides a summary of the AML/CFT measures in place in Finland, the level of compliance with the FATF 40+9 Recommendations, and contains recommendations on how the AML/CFT system could be strengthened. The assessment is based on the information available at the time it was completed in June 2007 and was produced using the 2004 Assessment Methodology. The views expressed in this document have been agreed by the FATF and Finland, but do not necessarily reflect the views of the Boards of the IMF or World Bank.

2. Finland has a good legal structure to combat money laundering and terrorist financing. The money laundering offence established in 2003 is broad and encompasses most of the elements of the Vienna and Palermo Conventions. It is not possible to prosecute for self-laundering and this is not due to any fundamental principle of Finnish law. The terrorist financing offence is also broad though it is likely that a link to a specific terrorist act is required for prosecution of terrorist financing. There have been few convictions for money laundering and no prosecutions for terrorist financing. While the Penal Code provides the ability to restrain, confiscate and recover the proceeds of crime in most situations, Finland has not established a complete mechanism for freezing terrorist assets. Overall, the Finnish FIU is effective and is the focal point for Finnish AML/CFT efforts. Finland has designated competent authorities to investigate and prosecute money laundering and terrorist financing offences. Measures for domestic and international co-operation are generally comprehensive as well.

3. The preventive system addresses customer identification and other AML/CFT obligations and applies to a range of financial institutions and most of the designated non-financial businesses and professions (DNFBPs) as defined by the FATF. It does not however incorporate customer due diligence (CDD) requirements with respect to beneficial ownership or legal arrangements and no provisions have been implemented with respect to politically exposed persons or correspondent banking relationships. The legal concept of trust does not exist under Finnish law. Record keeping requirements are comprehensive and the suspicious transaction reporting requirement is sound.

4. While the volume of suspicious transaction reports (STRs) has increased in recent years, there is significant disparity in the reporting volume both within and between different financial sectors. The STR reporting requirement is sound but could be strengthened. Supervision is generally effective for the banking and insurance sectors, but AML/CFT supervision is weak or non-existent for many types of designated non-financial businesses and professions (DNFBPs) and limited AML/CFT guidance has been issued, in particular to DBFBPs. The number of detected violations and the number of sanctions imposed are low. In some areas the available sanctions are not strong.

\section{Legal Systems and Related Institutional Measures}

5. Finland has a democratic parliamentary system with a written Constitution and a clear separation of powers. It has a civil law legal system with legislative power vested in the Parliament. Finland has one self-governing territory; the Åland Islands. Finland has a notably low level of corruption and promotes access by the public to official documents and other information from the government. The major sources of illegal proceeds in Finland relate to financial and drug-related crimes and the majority of suspicious financial activities investigated have an international dimension. While the amount of money laundering cannot be precisely determined, it is estimated that the damage caused by crime and 
the black economy exceeds EUR 5 billion each year. Finland has not, to date, conducted any terrorist financing investigations or prosecutions and the threat from terrorist financing does not appear strong.

6. The Penal Code contains offences of money laundering (ML), aggravated ML, conspiracy to commit aggravated ML, negligent ML and other ML violations. These offences originated in the receiving offence. In 2003, the Penal Code was again amended, and the current ML offences were added as clearly independent from the receiving offence. In Finland, any offence can be a predicate offence of ML. The ML offence encompasses most of the elements of the Vienna and Palermo Conventions, though not possession of proceeds of crime or acquisition or use of such property without intention to conceal its illegal origin. It is not possible to prosecute persons for laundering the proceeds of his/her own criminal activity and this is not due to any fundamental principle of Finnish law. There have been few convictions for money laundering. The number of prosecutions for ML offences in Finland is low and the sentences provided for ML convictions are low.

7. Terrorist financing (TF) was criminalised under the Penal Code in 2003. At the same time, the scope of application of the system for preventing and investigating ML was extended to include preventing and investigating the financing of terrorism. The TF provision does not cover financing of a terrorist organisation or of an individual terrorist where there is no link to a specific terrorist act or terrorist acts that will occur in the future. Finland has not, to date, conducted any TF investigations or prosecutions.

8. While the Penal Code provides the ability to restrain, confiscate and recover the proceeds of crime in most situations, Finland has not established a complete mechanism for freezing terrorist assets. In ML cases, provisional measures may be used only when the proceeds of crime can be identified and when a connection to the offence from which the proceeds were derived can be proven. This limits the scope of application of provisional measures. There are also some gaps in the confiscation provisions. It is not possible to: confiscate property of organisations that are found to be primarily criminal in nature without a link to a certain crime; confiscate proceeds which are completely mingled with licit assets; void actions where the persons involved knew or should have known that as a result of those actions the authorities would be prejudiced in their ability to recover property subject to confiscation. It appears that the recovery of assets is generally effective but with respect to ML is low, possibly due to the focus on investigation of predicate offences rather than investigation of ML. The amount of recovered property has not increased in recent years.

9. As a member of the European Union (EU), Finland is bound by EU mechanisms to implement UN obligations with respect to freezing of funds used for TF. Finland has not enacted domestic measures to expand the coverage of the EU mechanisms. The mechanisms in Finland do not apply to persons, groups or entities within the EU, nor is there a domestic mechanism for considering requests from other States for freezing of terrorist assets. Finland's mechanisms also do not explicitly cover funds owned, "directly or indirectly" by designated persons, or those controlled directly or indirectly, by designated persons. There is no national procedure for unfreezing funds or other assets of persons or entities inadvertently affected by freezing mechanisms. In addition, the limited nature of the TF offence in Finland impacts on the scope of the terrorist asset freezing regime. Finland has issued little guidance to entities that may be holding targeted funds in Finland and communication with entities outside the banking, and insurance sectors about terrorist asset matters is limited. No terrorist assets have been frozen in Finland pursuant to the UN or EU sanctions.

10. The Money Laundering Clearing House (MLCH), Finland's financial intelligence unit (FIU), was established in 1998. It is an independent unit situated within the National Bureau of Investigation (NBI) of the Finnish Police. In addition to receipt, analysis and dissemination of STRs, the MLCH is involved in pre-trial investigations of ML and TF offences. The MLCH has a range of powers to obtain information for its analysis and investigations and it has direct access to a number of government and public databases. The FIU meets many of the requirements of Recommendation 26 and clearly plays a key role in the AML/CFT system in Finland. However, there are several factors that diminish the FIU's effectiveness. As at the time of the on-site visit, there was a backlog of reports to be 
entered into the MLCH database ${ }^{1}$. Moreover, limited resources are in place with respect to guidance to obliged parties and development of trends and typologies and the current IT system is limited in functionality. Mechanisms to obtain information on the outcomes of disseminated matters are weak. Few disclosures are received on the basis of suspicion of TF and these are almost entirely due to possible name matches with persons on the $\mathrm{UN}$ and EU terrorist lists.

11. Finland has designated authorities to investigate ML and TF offences and equipped them with necessary powers. Investigation authorities include the Finnish Police, Finnish Customs (though it is not a competent authority with respect to TF) Border Guard, Security Police and the MLCH. The primary unit responsible for investigating ML and TF is the National Bureau of Investigations (NBI). Investigations into TF are the joint responsibility of the NBI and the Security Police. Public prosecutors prosecute all offences in Finland but they do not direct investigations. The various agencies appear adequately structured, funded and resourced to effectively carry out their functions though the resources could be focussed more on ML and TF matters.

12. As of 15 June 2007, Finland implemented a declaration system for cross-border movements of cash of EUR 10000 or more when the EU Council Regulation 1889/2005: "the Cash Controls Regulation" and the Finnish Act on the controls of cash entering or leaving the European Community (653/2007) entered into force. As indicated by its title, this legislation only covers the transfer of cash or bearer negotiable instruments when entering or leaving the European Union territory. Cross-border declarations of currency or monetary instruments are being provided to the MLCH by Finnish Customs. As these measures are very new, it is too early to ascertain the effectiveness of this system.

\section{Preventive Measures - Financial Institutions}

13. Finland's financial sector is dominated by the banking sector, and in particular by three bank groups. The application of the Finnish AML/CFT measures to the financial system and to DNFBPs is not based on risk assessment in the manner contemplated in the revised FATF 40 Recommendations. The preventive system and other AML/CFT obligations apply to a range of financial institutions and most of the designated non-financial businesses and professions (DNFBPs) as defined by the FATF. Obliged parties must identify and verify the identities of persons conducting transactions. It does not incorporate customer due diligence (CDD) requirements with respect to beneficial ownership, the identification process to be conducted with respect to legal arrangements is unclear, and no provisions have been implemented with respect to politically exposed persons or correspondent banking relationships. Some CDD exemptions are in place in the banking and insurance sectors.

14. The legal concept of trust does not exist under Finnish law. The only requirements to understand the ownership and control structure of the customer exist as part of enhanced due diligence. The enhanced due diligence obligation is narrow in scope; covering only NCCT-listed countries. There are no clear requirements for money remitters and foreign exchange companies to know the nature, scope and purpose of their customer relations and transactions. There are no requirements for obliged parties to have measures in place for prevention of the misuse of technological developments in ML or TF. Limited provisions are in place with respect to the risks associated with non- face to face business relationships and transactions. Although financial institutions may rely on third parties to conduct CDD for them, and do so within financial services groups, there are no provisions in the $A M L / C F T$ Act or elsewhere with respect to these situations.

15. There are no limitations on the power of authorities in Finland to obtain information in the course of their duties and record-keeping requirements are comprehensive. The measures in place with respect to customer information accompanying cross-border wire transfers are strong but they do not

1 In August 2007, the MLCH advised that inputting to the database was up to date and this backlog no longer existed. 
apply to wire transfers within the EU and there are no provisions on penalties applicable to infringements of the wire transfer requirements for the remittance sector.

16. The customer due diligence obligation provides that all obliged parties in Finland must examine the grounds for and the purpose of the use of its services where transactions are unusual in respect of composition or scale (structure or size), or if they have no apparent financial purpose, or if they are inconsistent with the financial situation or other activities or transactions of a customer. There is no requirement however for the obliged parties to set forth their findings in writing.

17. There are no CDD requirements with respect to politically exposed persons or with respect to correspondent banking relationships. While there is no direct explicit prohibition against establishing or operating a shell bank, licensing requirements for banks would in practice exclude a bank or other institution with no physical address from gaining a license to operate. There is no provision prohibiting banks or other institutions from having correspondent relationships with shell banks and there is no provision requiring institutions to satisfy themselves that their accounts at respondent institutions cannot be indirectly accessed by shell banks.

18. The STR reporting obligation is sound and applies regardless of the amount of the transaction. There is no requirement however to report transactions suspected of being related to terrorism other than those related to terrorist acts. A large percentage of local banking institutions are not filing suspicious transaction reports. Few reports have been received from securities institutions. The legislation provides immunity from prosecution for those persons who report suspicions to the MLCH in good faith. "Tipping off" others about STR reporting is an offence. The Finnish AML/CFT system requires only STR reporting as authorities considered the benefits of a currency transaction reporting some time ago but decided not to implement such a system.

19. The various procedures for licensing financial institutions appear generally sound. The qualifications and fit and proper tests for persons operating in senior roles in this sector, however, are sometimes vague. For entities supervised by the Financial Supervisory Authority (FSA) and the Insurance Supervision Authority (ISA), on-going supervision of compliance with AML/CFT obligations is carried out primarily as part of prudential oversight and as part of risk management, internal control and code of conduct supervision. The FSA, ISA and MLCH have issued guidance and standards to assist obliged parties to implement and comply with their obligations, but limited guidance has been issued specifically on AML/CFT matters. For FSA and ISA-supervised entities, AML/CFT supervision is carried out primarily as part of prudential oversight and as part of risk management, internal control and code of conduct supervision. Both authorities could more actively conduct AML/CFT-focussed inspections and supervision and could strengthen off-site AML/CFT control. FSA supervision of financial institutions covers the entire financial group, including foreign branches. The FSA also supervises that the branches of foreign credit institutions, investment firms and fund management companies in Finland comply with the Finnish AML/CFT laws and regulations. There are no similar requirements concerning foreign branches of other financial entities. Although licencing procedures would likely prevent a bank or securities firm from establising a branch or subsidiary in a jurisdiction that had not adequately implemented FATF standards, there is no requirement that these businesses notify the FSA or the MLCH if their foreign branches or subsidiaries were to be prevented by local rules from observing AML/CFT measures.

20. The money remittance and foreign exchange sectors do not have a supervisory authority, nor are there rules that require these businesses to have internal controls, compliance officers, and training to ensure compliance with AML/CFT obligations. Remittance services are subject to registration requirements.

21. In the absence of a designated AML supervisor, the money remittance and foreign exchange sector is subject only to criminal sanctions, while entities supervised by the FSA and ISA are subject to additional administrative penalties. The ISA has a relatively limited range of sanctions available to it. While they are in line with the usual scale of punishments in Finland, the penalties which may be 
imposed under the $A M L / C F T$ Act and those available to the FSA and ISA are relatively low. Finnish regulatory authorities rarely apply their sanction powers and only once has a sanction been imposed for matters relation to AML/CFT obligations.

\section{Preventive Measures - Designated Non-Financial Businesses and Professions}

22. Finland encapsulates a range of designated non-financial businesses and professions as obliged parties. The only type of DNFBP, as defined by the FATF, which is not covered is trust and company service providers. The covered DNFBPs are subject to the same requirements as financial institutions to identify customers, keep records, conduct ongoing due diligence, conduct enhanced due diligence where required, report suspicious transactions to the MLCH and suspend transactions where appropriate. There is little indication that dealers in precious metals and precious stones are complying with their AML/CFT obligations and many types of DNFBPs are submitting very few STRs to the $\mathrm{MLCH}$. In addition, there is a lack of clarity regarding the legal obligations (and resulting supervisory practices) for the gaming operator in the Åland Islands and this could obstruct consistent enforcement of AML/CFT measures across the entire Finnish gaming sector.

23. Gaming operators, auditors, advocates and real estate agents have designated supervisors to monitor compliance with various regulatory requirements. Although most consider the fulfilment of AML/CFT obligations part of the risk management of the institution, none provides robust AML/CFT supervision. Other DNFBPs are not supervised for compliance with AML/CFT requirements. No guidance has been provided focussing on the AML/CFT risks to which the various industries / businesses / products of the DNFBPs are exposed.

\section{Legal Persons and Arrangements \& Non-Profit Organisations}

24. While Finland has a good trade registry system for legal persons, only relatively general information is required for the trade registry and this is insufficient to determine beneficial ownership and control. Measures are in place to ensure companies submit their annual accounts, and lack of compliance with this may be sanctioned. All Finnish companies, co-operatives, partnerships and other private business entities have to register with the National Board of Patents and Registration (the PRH) and be entered in the trade register, the associations register, the foundations register or the register of persons subject to business prohibition and floating charges. Any changes of the information registered in the Trade Register - such as changes to a limited liability company's name, business activities, address, board members or share capital - have to be notified to and registered immediately with the PRH. In addition, all limited companies, partnership, co-operatives and mutual insurance companies, are also obliged to submit their annual accounts and auditor's reports to PRH. Requirements that limited liability companies maintain share registers and shareholder registers are not supervised by a government authority.

25. The Finnish legal system does not allow for the creation of trusts, and the legal concept of trust does not exist under Finnish law. Foreign trusts may operate in Finland. If a foreign trust comes to a Finnish financial institution as a customer, it is treated as any other legal person which is a customer of the financial institution.

26. Finland's trade registry system and accounting requirements apply to foundations and to those associations which choose to register, and a clear process is in place for authorities to manage the money collection activities of non-profit organisations. While Finland is beginning to place greater attention and resources into work with the non-profit sector, it has not conducted a review of the sector and limited supervision and sanctions are in place to deal with inappropriate conduct in the sector. 


\section{National and International Co-operation}

27. Co-operation between the various stakeholders in Finland is strong, both on a formal and informal level. The various authorities involved in AML/CFT are co-ordinating their efforts on operational and policy matters, though co-operative projects could more specifically target ML and TF issues. In addition, there is a lack of feedback and information sharing between agencies which limits the ability of the MLCH and others to completely examine the effectiveness of the system. This is at least in part due to weak information management systems, particularly with respect to collection and analysis of statistics, and limited interagency connectivity between the various systems. It is also a result of the emphasis on regular contact rather than structured co-ordination.

28. Finland has ratified and implemented, with some shortcomings as noted previously, the Vienna, Palermo and TF Conventions and the provisions of S/RES/1267(1999) and S/RES/1373(2001). There are no unduly restrictive measures placed on the provision of mutual legal assistance. Under Finland's International Legal Assistance in Criminal Matters Act, Finnish authorities are expected to provide legal assistance to the fullest extent possible. Execution of requests for mutual legal assistance does not require dual criminality unless the request is for the use of coercive measures. The possibilities to carry out requests from foreign countries for identification, freezing, seizure or confiscation are in principle the same as if the offence or a suspicion of an offence has occurred in Finland. Finland has not considered establishing an asset forfeiture fund to share confiscated assets with other jurisdictions or to fund relevant national initiatives.

29. Money laundering and terrorist financing are extraditable offences, though dual criminality is required for extraditions other than to EU member States or Nordic countries. The dual criminality requirement means extradition could be refused in cases where the Finnish ML or TF offence is limited. Requests are not agreed to for extradition of a Finnish citizen to a country other than an EU member state or a Nordic country.

30. Finnish authorities are satisfied with international co-operation concerning the FIU and law enforcement authorities. There are no indications that co-operation would be ineffective or would not be used as provided in the FATF Recommendations. Although the MLCH and the FSA maintain some statistics concerning international co-operation, these are insufficient to fully assess the effectiveness of the system.

\section{Resources and Statistics}

31. On the whole, competent authorities appear to be adequately resourced and structured to effectively perform their functions. However, planned upgrades to the MLCH's IT systems are expected to provide welcome additional functionality and the MLCH would benefit from additional staff. There is no AML/CFT supervisor for the money remittance and currency exchange sectors. Resources could be directed towards ML/TF investigations rather than focussing on predicate crimes, and resources could be put into awareness-raising and into development of trends, typologies and guidance.

32. The extent of statistics held by authorities is variable. The FIU only produces limited statistics and has limited information on the outcomes of STRs referred for pre-trial investigation. Statistics on $\mathrm{ML} / \mathrm{TF}$ investigations and on property frozen, seized or confiscated are not comprehensive. Limited statistics are kept with regard to the informal (not on the basis of MLA) exchange of information between the Finnish LEA and foreign LEAs. Finland does not review the effectiveness of its preventative AML/CFT system. 


\section{Table 1: Ratings of Compliance with FATF Recommendations}

The rating of compliance vis-à-vis the FATF Recommendations has been made according to the four levels of compliance mentioned in the 2004 Methodology $^{2}$ (Compliant (C), Largely Compliant (LC), Partially Compliant (PC), Non-Compliant (NC)), or, in exceptional cases, Not Applicable (N/A).

\begin{tabular}{|c|c|}
\hline Compliant & The Recommendation is fully observed with respect to all essential criteria. \\
\hline $\begin{array}{l}\text { Largely } \\
\text { Compliant }\end{array}$ & $\begin{array}{l}\text { There are only minor shortcomings, with a large majority of the essential criteria being fully } \\
\text { met. }\end{array}$ \\
\hline $\begin{array}{l}\text { Partially } \\
\text { Compliant }\end{array}$ & $\begin{array}{l}\text { The country has taken some substantive action and complies with some of the essential } \\
\text { criteria. }\end{array}$ \\
\hline Non Compliant & There are major shortcomings, with a large majority of the essential criteria not being met. \\
\hline Not Applicable & $\begin{array}{l}\text { A requirement or part of a requirement does not apply, due to the structural, legal or } \\
\text { institutional features of a country e.g. a particular type of financial institution does not exist } \\
\text { in that country. }\end{array}$ \\
\hline
\end{tabular}

\begin{tabular}{|c|c|c|}
\hline Recommendations & Rating & Summary of Factors Underlying Rating ${ }^{3}$ \\
\hline \multicolumn{3}{|l|}{ Legal systems } \\
\hline 1-ML offence & $\mathrm{PC}$ & $\begin{array}{l}\text { - Not all physical elements (mere acquisition, possession and use of } \\
\text { property) of the criminal offence of money laundering are covered. } \\
\text { - It is not possible to prosecute for self-laundering and this is not due } \\
\text { to any fundamental principle of Finnish law. } \\
\text { - It is not possible to prosecute for money laundering any person living } \\
\text { in a joint household with the offender who only uses or consumes } \\
\text { property obtained by the offender for ordinary needs in the joint } \\
\text { household. } \\
\text { - There is no offence of conspiracy available for the basic offence of } \\
\text { money laundering and this is not due to any fundamental principle of } \\
\text { Finnish law. } \\
\text { - The ML offence has not been effectively implemented as there have } \\
\text { been very few convictions for money laundering, and the numbers } \\
\text { appear to be decreasing since the latest amendments to the law } \\
\text { were made. }\end{array}$ \\
\hline $\begin{array}{l}2-\mathrm{ML} \text { offence - mental } \\
\text { element and corporate } \\
\text { liability }\end{array}$ & LC & $\begin{array}{l}\text { - The maximum punishment for conspiracy seems too low when the } \\
\text { seriousness of the offence is taken into account. } \\
\text { - The maximum corporate fine is very low when both the seriousness } \\
\text { of offences that may occur and the economic strengths of the entities } \\
\text { in question are taken into account. } \\
\text { - Corporate fines are very seldom used. }\end{array}$ \\
\hline $\begin{array}{l}3 \text { - Confiscation and } \\
\text { provisional measures }\end{array}$ & LC & $\begin{array}{l}\text { - It is not possible to confiscate property of value corresponding to the } \\
\text { laundered proceeds. } \\
\text { - It is not possible to confiscate laundered proceeds that are mingled } \\
\text { with licit assets to such an extent that the licit / illicit origin cannot be } \\
\text { distinguished. } \\
\text { - It is not clear that the rights of bona fide third parties would be } \\
\text { protected in all circumstances. } \\
\text { - Provisional measures are not often used due to the high burden of } \\
\text { having to demonstrate a material link between the property and an }\end{array}$ \\
\hline
\end{tabular}

2 Methodology for Assessing Compliance with the FATF 40 Recommendations and the FATF 9 Special Recommendations, 27 February 2004 (Updated as of February 2007).

3 These factors are only required to be set out when the rating is less than Compliant. 


\begin{tabular}{|c|c|c|}
\hline Recommendations & Rating & Summary of Factors Underlying Rating ${ }^{3}$ \\
\hline & & $\begin{array}{l}\text { offence and the likelihood that there would be flight or removal of the } \\
\text { property. } \\
\text { - Due to a lack of detail in statistics held on confiscation it is difficult to } \\
\text { assess effectiveness in this area. }\end{array}$ \\
\hline \multicolumn{3}{|l|}{ Preventive measures } \\
\hline 4 - Secrecy laws & $\mathrm{C}$ & - This Recommendation is fully observed. \\
\hline $\begin{array}{l}5 \text { - Customer due } \\
\text { diligence }\end{array}$ & PC & $\begin{array}{l}\text { - There are no requirements to identify the beneficial owners of legal } \\
\text { persons. } \\
\text { - There are no general requirements to understand the ownership and } \\
\text { control structure of the customer, other than as part of enhanced due } \\
\text { diligence. } \\
\text { - The identification process to be conducted in relation to legal } \\
\text { arrangements is unclear. } \\
\text { - There is no requirement to conduct ongoing due diligence on the } \\
\text { business relationship. } \\
\text { - There are no clear requirements for money remitters and foreign } \\
\text { exchange companies to know the nature, scope and purpose of their } \\
\text { customer relations and transactions. } \\
\text { - Some CDD exemptions are in place in the banking and insurance } \\
\text { sectors. } \\
\text { - The enhanced due diligence obligation is very narrow in scope; } \\
\text { covering only NCCT-listed countries. }\end{array}$ \\
\hline $\begin{array}{l}6 \text { - Politically exposed } \\
\text { persons }\end{array}$ & NC & $\begin{array}{l}\text { - There are no CDD requirements with respect to politically exposed } \\
\text { persons. }\end{array}$ \\
\hline $\begin{array}{l}7 \text { - Correspondent } \\
\text { banking }\end{array}$ & NC & $\begin{array}{l}\text { - There are no CDD requirements with respect to correspondent } \\
\text { banking relationships. }\end{array}$ \\
\hline $\begin{array}{l}8-\text { New technologies \& } \\
\text { non face-to-face business }\end{array}$ & PC & $\begin{array}{l}\text { - There are no requirements for obliged parties to have measures in } \\
\text { place for prevention of the misuse of technological developments in } \\
\text { ML or TF. } \\
\text { - Limited provisions are in place with respect to the risks associated } \\
\text { with non- face to face business relationships and transactions. }\end{array}$ \\
\hline $\begin{array}{l}9-\text { Third parties and } \\
\text { introducers }\end{array}$ & NC & $\begin{array}{l}\text { - In some situations third parties are relied upon to perform elements } \\
\text { of CDD, but this is not regulated. } \\
\text { - Financial institutions are not required to immediately obtain from the } \\
\text { third party the necessary information concerning the CDD process. } \\
\text { - Insurance companies are not required to take adequate steps to } \\
\text { satisfy themselves that copies of identification data and other } \\
\text { relevant documentation relating to CDD will be made available from } \\
\text { the third party upon request without delay. } \\
\text { - Financial institutions are not required to satisfy themselves that the } \\
\text { third party is regulated and supervised and has measures in place to } \\
\text { comply with CDD requirements. } \\
\text { - There are no provisions to establish that the ultimate responsibility } \\
\text { for customer identification remains with the financial institution } \\
\text { relying on a third party. }\end{array}$ \\
\hline 10 - Record keeping & $\mathrm{C}$ & - This Recommendation is fully observed. \\
\hline 11 - Unusual transactions & PC & $\begin{array}{l}\text { - For institutions not supervised by the FSA, there is no requirement to } \\
\text { keep records of findings of examinations of unusual transactions. }\end{array}$ \\
\hline
\end{tabular}




\begin{tabular}{|c|c|c|}
\hline Recommendations & Rating & Summary of Factors Underlying Rating ${ }^{3}$ \\
\hline & & $\begin{array}{l}\text { - Due to the lack of record-keeping requirement for institutions not } \\
\text { supervised by the FSA, it is difficult to assess whether the obligation } \\
\text { to examine unusual transactions is in fact being observed. }\end{array}$ \\
\hline $\begin{array}{l}12 \text { - DNFBPs - R.5, 6, 8- } \\
11\end{array}$ & NC & $\begin{array}{l}\text { - Trust and company service providers are not obliged parties. } \\
\text { - Finland's shortcomings in implementation of Recommendations } 5 \text { - } 8 \\
\text { and } 10 \text { - } 11 \text { also apply to DNFBPs. } \\
\text { - There is no indication that dealers in previous metals and precious } \\
\text { stones are complying with their AML/CFT obligations. } \\
\text { - There is a lack of clarity with respect to the AML/CFT obligations for } \\
\text { gaming businesses in the Åland Islands. }\end{array}$ \\
\hline $\begin{array}{l}13 \text { - Suspicious } \\
\text { transaction reporting }\end{array}$ & LC & $\begin{array}{l}\text { - There is no requirement to report transactions suspected of being } \\
\text { related to terrorism other than those related to terrorist acts and no } \\
\text { requirement to report transactions suspected of being related to } \\
\text { terrorist organisations or to those who finance terrorism. } \\
\text { - A large percentage of local banking institutions are not filing } \\
\text { suspicious reports. Few reports have been received from any } \\
\text { securities institutions. } \\
\text { - Effectiveness issue: For money remitters and foreign exchange, the } \\
\text { threshold-based reporting discourages meaningful due diligence to } \\
\text { subjectively evaluate whether activity is suspicious. }\end{array}$ \\
\hline $\begin{array}{l}14-\text { Protection \& no } \\
\text { tipping-off }\end{array}$ & C & - This Recommendation is fully observed. \\
\hline $\begin{array}{l}15 \text { - Internal controls, } \\
\text { compliance \& audit }\end{array}$ & PC & $\begin{array}{l}\text { - The Money Laundering Clearing House Best Practices, which would } \\
\text { satisfy many of the elements of Recommendation 15, are not } \\
\text { binding. } \\
\text { - There is no explicit requirement for money remittance and foreign } \\
\text { exchange sectors to develop internal controls or independent audit } \\
\text { to ensure compliance with the AML/CFT Act. } \\
\text { - There is no requirement for non- FSA-supervised entities to have } \\
\text { comprehensive training that focuses not only on internal procedures } \\
\text { and regulatory requirements, but also ML/TF typologies. } \\
\text { - Non-FSA supervised entities have no employee screening } \\
\text { requirements. } \\
\text { - There is no legal requirement for money remittance and foreign } \\
\text { exchange sectors to have compliance officers. }\end{array}$ \\
\hline $\begin{array}{l}16-\text { DNFBPs - R.13-15 \& } \\
21\end{array}$ & PC & $\begin{array}{l}\text { - Trust and company service providers are not obliged parties. } \\
\text { - Finland's shortcomings in implementation of Recommendation } 13 \\
\text { also apply to DNFBPs. } \\
\text { - There is no requirement to report transactions suspected of being } \\
\text { related to terrorism other than those related to terrorist acts and no } \\
\text { requirement to report transactions suspected of being related to } \\
\text { terrorist organisations or to those who finance terrorism. } \\
\text { - DNFBPs are not required to have internal controls, compliance } \\
\text { officers, independent audits for AML/CFT, ongoing training or } \\
\text { employee screening. } \\
\text { - There is a lack of clarity with respect to the AML/CFT obligations for } \\
\text { gaming businesses in the Åland Islands and only one STR has been } \\
\text { submitted from that sector to date. } \\
\text { - Few STRs have been submitted by the other DNFBPs, which calls } \\
\text { into question the effectiveness of Recommendation } 13 \text { in this sector. }\end{array}$ \\
\hline 17 - Sanctions & PC & - Money remitters and foreign exchange offices are subject only to \\
\hline
\end{tabular}




\begin{tabular}{|c|c|c|}
\hline Recommendations & Rating & Summary of Factors Underlying Rating ${ }^{3}$ \\
\hline & & $\begin{array}{l}\text { - The scope of regulatory authorities' ability to sanction natural } \\
\text { persons, such as directors or senior management of institutions, is } \\
\text { unclear. } \\
\text { - The ISA has a relatively limited range of sanctions available to it. } \\
\text { - Finnish regulatory authorities rarely apply their sanction powers and } \\
\text { have only once applied them for matters relating to AML/CFT } \\
\text { obligations. }\end{array}$ \\
\hline 18 - Shell banks & PC & $\begin{array}{l}\text { - There is no provision prohibiting banks or other institutions from } \\
\text { having correspondent relationships with shell banks. } \\
\text { - There is no provision requiring institutions to satisfy themselves that } \\
\text { their accounts at respondent institutions do not allow indirect access } \\
\text { by shell banks to those accounts. }\end{array}$ \\
\hline $\begin{array}{l}19-\text { Other forms of } \\
\text { reporting }\end{array}$ & C & - This Recommendation is fully observed. \\
\hline $\begin{array}{l}20 \text { - Other NFBP \& } \\
\text { secure transaction } \\
\text { techniques }\end{array}$ & $\mathrm{C}$ & - This Recommendation is fully observed. \\
\hline $\begin{array}{l}21-\text { Special attention for } \\
\text { higher risk countries }\end{array}$ & PC & $\begin{array}{l}\text { - Due to the absence of a requirement to set forth in writing the } \\
\text { findings of examinations of unusual transactions, it is difficult to } \\
\text { assess whether the obligation to examine the purpose of } \\
\text { transactions with no apparent economic or visible lawful purpose } \\
\text { involving countries or territories which do not or insufficiently apply } \\
\text { the FATF Recommendations is in fact being observed. } \\
\text { - The only possible counter-measure is application of enhanced } \\
\text { customer identification processes. } \\
\text { - There is no evidence that non-FSA supervised entities have } \\
\text { mechanisms in place to receive notifications from a supervisory } \\
\text { authority regarding countries or territories which do not or } \\
\text { insufficiently apply the FATF Recommendations. }\end{array}$ \\
\hline $\begin{array}{l}22 \text { - Foreign branches } \& \\
\text { subsidiaries }\end{array}$ & PC & $\begin{array}{l}\text { - There are no relevant requirements for non-FSA supervised } \\
\text { businesses. } \\
\text { - Banks and securities are only authorised, not required, to provide } \\
\text { notice to the FSA or the MLCH when their foreign branches or } \\
\text { subsidiaries are prevented by local rules from observing AML/CFT } \\
\text { measures. }\end{array}$ \\
\hline $\begin{array}{l}23 \text { - Regulation, } \\
\text { supervision and } \\
\text { monitoring }\end{array}$ & PC & $\begin{array}{l}\text { - The number of inspections specifically focussed on AML/CFT } \\
\text { matters is very low. } \\
\text { - There is not relevant supervisor for the money exchange and } \\
\text { remittance sectors. } \\
\text { - There are no provisions to prevent criminals from holding a } \\
\text { controlling interest in institutions operating in the money exchange or } \\
\text { remittance sectors. } \\
\text { - } \\
\text { inf-site AML/CFT control is limited; it is based on periodic reports by } \\
\text { do not address requirements relating to AML/CFT. }\end{array}$ \\
\hline $\begin{array}{l}24 \text { - DNFBP - regulation, } \\
\text { supervision and } \\
\text { monitoring }\end{array}$ & NC & $\begin{array}{l}\text { - It is unclear what } \mathrm{AML} / \mathrm{CFT} \text { obligations and thus } \mathrm{AML} / \mathrm{CFT} \\
\text { supervisory regime apply to Casino PAF on the Âland Islands. } \\
\text { - Casinos are subject only to the general requirements in the } \\
A M L / C F T \text { Act - with no additional requirements or binding standards } \\
\text { in place to govern their conduct regarding AML issues. } \\
\text { - It is unclear whether limited (criminal) sanctions can be applied to }\end{array}$ \\
\hline
\end{tabular}




\begin{tabular}{|c|c|c|}
\hline Recommendations & Rating & Summary of Factors Underlying Rating ${ }^{3}$ \\
\hline & & $\begin{array}{l}\text { directors and management of all DNFBPs. } \\
\text { - As SRO membership for accountants and lawyers is voluntary, parts } \\
\text { of each sector receive no guidance and are completely } \\
\text { unsupervised. } \\
\text { - Trust and company service providers are not regulated or supervised } \\
\text { in any way, and while trusts are not recognised in Finnish law, } \\
\text { company service providers are operating. } \\
\text { - There is no supervisory authority for dealers in precious metals and } \\
\text { stones }\end{array}$ \\
\hline $\begin{array}{l}25 \text { - Guidelines \& } \\
\text { Feedback }\end{array}$ & PC & $\begin{array}{l}\text { - Limited guidance on AML/CFT matters has been issued to obliged } \\
\text { parties and only one piece of guidance has been issued on STR } \\
\text { reporting. } \\
\text { - Guidance does not comprehensively address all areas of the FATF } \\
\text { Recommendations. } \\
\text { - No guidance has been issued which specifically addresses } \\
\text { AML/CFT issues of relevance for the money exchange and } \\
\text { remittance sector or for any DNFBPs. } \\
\text { - SRO best practices are not distributed to all in the accounting/legal } \\
\text { sectors as participation in SROs is voluntary. } \\
\text { - TCSPs are not subject to any regulation or guidance. } \\
\text { - Dealers have no supervisor to provide them guidance other than the } \\
\text { MLCH. In practice, supervisors of the money remittance, the foreign } \\
\text { exchange and the real estate sectors do not provide any feedback or } \\
\text { guidance, other than that which is provided by MLCH. The MLCH, } \\
\text { however, lacks the resources to provide the kind of individual } \\
\text { feedback that a robust supervisory system could provide. } \\
\text { - Some general feedback is provided to financial institutions and } \\
\text { DNFBPs but does not include information on current techniques, } \\
\text { methods and trends (typologies). } \\
\text { - Non-FSA/ISA supervisors rely completely on the MLCH to provide } \\
\text { guidance and limited guidance documents have been issued by the } \\
\text { MLCH to date. }\end{array}$ \\
\hline \multicolumn{3}{|c|}{ Institutional and other measures } \\
\hline 26 - The FIU & LC & $\begin{array}{l}\text { - There was at the time of this assessment a five-month backlog in } \\
\text { inputting STRs to the FIU's database. } \\
\text { - Little written guidance has been provided to obliged parties } \\
\text { regarding the manner of reporting and these parties have made } \\
\text { limited use of the ability to submit STRs electronically. } \\
\text { - The feedback provided to obliged parties by the FIU and the analysis } \\
\text { conducted by the FIU are limited by insufficient human and technical } \\
\text { resources. }\end{array}$ \\
\hline $\begin{array}{l}27 \text { - Law enforcement } \\
\text { authorities }\end{array}$ & LC & $\begin{array}{l}\text { - Insufficient attention is being paid to pursuing ML and TF offences; } \\
\text { authorities are instead focussing their efforts on predicate offences } \\
\text { and recovery of proceeds of crime. } \\
\text { - Due to a lack of statistics it is difficult to evaluate the effectiveness of } \\
\text { the system. }\end{array}$ \\
\hline $\begin{array}{l}28 \text { - Powers of competent } \\
\text { authorities }\end{array}$ & $\mathrm{C}$ & - This Recommendation is fully observed. \\
\hline 29 - Supervisors & PC & $\begin{array}{l}\text { - Money remittance and currency exchange sectors are not } \\
\text { adequately supervised for AML/CFT compliance by any supervisor, } \\
\text { and are not subject to AML/CFT inspections. } \\
\text { - The infrequent use of the FSA's and ISA's enforcement powers does }\end{array}$ \\
\hline
\end{tabular}




\begin{tabular}{|c|c|c|}
\hline Recommendations & Rating & Summary of Factors Underlying Rating ${ }^{3}$ \\
\hline & & not allow for meaningful assessment of their effectiveness. \\
\hline $\begin{array}{l}30-\text { Resources, integrity } \\
\text { and training }\end{array}$ & PC & $\begin{array}{l}\text { - There is no AML/CFT supervisor for the money remittance and } \\
\text { currency exchange sectors. } \\
\text { - It is not clear to what extent all supervisory employees are subject to } \\
\text { background checks for appropriate integrity and confidentiality } \\
\text { controls. } \\
\text { - There is a need for more staff in the FIU, and in particular, persons } \\
\text { who should focus on enhancing co-operation with institutions and } \\
\text { persons currently not disclosing, to develop more detailed feedback, } \\
\text { and to conduct ML/TF typologies development. } \\
\text { - The current database of the FIU does not provide all functionality } \\
\text { needed, particularly for analysis purposes and typologies } \\
\text { development. } \\
\text { - No statistics are maintained on spontaneous referrals made by the } \\
\text { FIU to foreign authorities. } \\
\text { - There is a need to raise the awareness of the pre-trial investigation } \\
\text { and prosecuting authorities to ML and TF issues through more } \\
\text { resources dedicated to producing guidance and typologies. }\end{array}$ \\
\hline 31 - National co-operation & LC & $\begin{array}{l}\text { - It is unclear how effective co-ordination is at targeting money } \\
\text { laundering or terrorist financing specifically, as these types of cases } \\
\text { are only pursued on a limited basis. } \\
\text { - There is limited information sharing and in particular feedback } \\
\text { between agencies with respect to investigations and results of inter- } \\
\text { agency disseminations. }\end{array}$ \\
\hline 32 - Statistics & PC & $\begin{array}{l}\text { - No stats on formal requests to/from the supervisory authorities. } \\
\text { - The FIU only produces limited statistics and should also keep } \\
\text { statistics about the follow up of the STRs referred for pre-trial } \\
\text { investigation; } \\
\text { - The statistics to be developed should be used for the analysis of the } \\
\text { performance of the MLCH and should therefore be shared with } \\
\text { partners on a national level. } \\
\text { - Statistics on ML / TF investigations and on property frozen, seized or } \\
\text { confiscated are not comprehensive. } \\
\text { - No statistics are kept with regard to the informal (not on the basis of } \\
\text { MLA) exchange of information between the Finnish LEA and foreign } \\
\text { LEAs. } \\
\text { - The effectiveness of the preventative AML/CFT system is not } \\
\text { reviewed. } \\
\text { - No statistics are maintained on spontaneous referrals made by the } \\
\text { FIU to foreign authorities. }\end{array}$ \\
\hline $\begin{array}{l}33 \text { - Legal persons - } \\
\text { beneficial owners }\end{array}$ & PC & $\begin{array}{l}\text { - There are no requirements for legal persons to keep or make } \\
\text { available information on beneficial ownership or control. } \\
\text { - There are limited requirements for legal persons to submit updated } \\
\text { information to the trade register. } \\
\text { - Requirements that limited liability companies maintain share } \\
\text { registers and shareholder registers are not supervised. }\end{array}$ \\
\hline $\begin{array}{l}34 \text { - Legal arrangements } \\
\text { - beneficial owners }\end{array}$ & N/A & - Trusts do no exist under Finnish law. \\
\hline \multicolumn{3}{|l|}{ International Co-operation } \\
\hline 35 - Conventions & PC & $\begin{array}{l}\text { - Some shortcoming exist in relation to implementation of article } 3(1) \\
\text { of the Vienna Convention and article 6(1) of the Palermo }\end{array}$ \\
\hline
\end{tabular}




\begin{tabular}{|c|c|c|}
\hline Recommendations & Rating & Summary of Factors Underlying Rating ${ }^{3}$ \\
\hline & & $\begin{array}{l}\text { Convention, namely the Finnish money laundering offence does not } \\
\text { criminalise all possession or acquisition of the proceeds of crime. } \\
\text { - Self-laundering is not an offence in Finland and this is not due to any } \\
\text { fundamental principle of law. } \\
\text { - The ancillary offence of conspiracy to money laundering is not } \\
\text { punishable, the conspiracy offence does not apply to all forms of the } \\
\text { aggravated money laundering offence, and members of a joint } \\
\text { household with the offender cannot be prosecuted if they only used } \\
\text { or consumed the proceeds of crime for ordinary needs in the joint } \\
\text { household. } \\
\text { - The sanctions for conspiracy to commit aggravated money } \\
\text { laundering and for participation in a criminal organisation are not } \\
\text { effective, proportionate and dissuasive. } \\
\text { - Article 18(1)(b) of the Terrorist Financing Convention is not fully } \\
\text { implemented, in particular the requirement for measures to ascertain } \\
\text { the identity of beneficial owners. }\end{array}$ \\
\hline $\begin{array}{l}36 \text { - Mutual legal } \\
\text { assistance (MLA) }\end{array}$ & LC & $\begin{array}{l}\text { - As dual criminality is required for exercise of coercive measures in } \\
\text { response to a mutual legal assistance request, the limitations in the } \\
\text { ML and TF offences limit the extent and effectiveness of mutual legal } \\
\text { assistance provided by Finland. } \\
\text { - Effectiveness could not be fully assessed due to limited statistics and } \\
\text { information on practical cases being available. }\end{array}$ \\
\hline 37 - Dual criminality & C & - This Recommendation is fully observed. \\
\hline $\begin{array}{l}38-\text { MLA on confiscation } \\
\text { and freezing }\end{array}$ & LC & $\begin{array}{l}\text { - It is not possible to confiscate property of corresponding value to the } \\
\text { proceeds derived from ML. } \\
\text { - Finland has not considered establishing an asset forfeiture fund. }\end{array}$ \\
\hline 39 - Extradition & LC & $\begin{array}{l}\text { - Conspiracy to conduct money laundering is not criminalised, the } \\
\text { offence of conspiracy to conduct aggravated ML laundering is limited } \\
\text { in scope, self-laundering is not an offence and funding a terrorist or a } \\
\text { terrorist organisation without a specific link to a terrorist act is not } \\
\text { punishable in Finland. These factors could be obstacles to } \\
\text { extradition limit the extraditions because of the requirement of dual } \\
\text { criminality. } \\
\text { - Effectiveness could not be fully assessed due to limited statistics and } \\
\text { information on practical cases being available. }\end{array}$ \\
\hline $\begin{array}{l}40 \text { - Other forms of co- } \\
\text { operation }\end{array}$ & LC & $\begin{array}{l}\text { - Statistics are not available which would allow for sufficient evaluation } \\
\text { of Finland's investment in international co-operation. }\end{array}$ \\
\hline \multicolumn{3}{|c|}{ Nine Special Recommendations } \\
\hline $\begin{array}{l}\text { SR.I - Implement UN } \\
\text { instruments }\end{array}$ & PC & $\begin{array}{l}\text { - Article } 18(1)(b) \text { of the Terrorist Financing Convention is not fully } \\
\text { implemented, in particular the requirement for measures to ascertain } \\
\text { the identity of beneficial owners. } \\
\text { - Finland does not have a national mechanism to give effect to } \\
\text { requests for freezing assets and designations from other jurisdictions } \\
\text { and it does not have a de-listing process. } \\
\text { - The definition of funds does not explicitly cover funds owned directly } \\
\text { or indirectly by designated persons or those controlled directly or } \\
\text { indirectly by designated persons. } \\
\text { - There are no procedures for accessing funds/assets that are frozen } \\
\text { and that are determined to be necessary on humanitarian grounds in } \\
\text { a manner consistent with S/RES/1452(2002). }\end{array}$ \\
\hline SR.II - Criminalise TF & LC & $\begin{array}{l}\text { - Funding a terrorist or a terrorist organisation without a specific link to } \\
\text { a terrorist act is not punishable in Finland. }\end{array}$ \\
\hline
\end{tabular}




\begin{tabular}{|c|c|c|}
\hline Recommendations & Rating & Summary of Factors Underlying Rating ${ }^{3}$ \\
\hline & & - The maximum corporate fine is very low. \\
\hline $\begin{array}{l}\text { SR.III - Freeze and } \\
\text { confiscate terrorist assets }\end{array}$ & PC & $\begin{array}{l}\text { - Finland does not have a national mechanism to consider requests } \\
\text { for freezing from other countries or to freeze the funds of EU } \\
\text { internals. } \\
\text { - The definition of funds in the EU regulations does not explicitly cover } \\
\text { funds owned 'directly or indirectly' by designated persons or those } \\
\text { controlled directly or indirectly by designated persons. } \\
\text { - Finland does not have an established national procedure for the } \\
\text { purpose of considering delisting requests. } \\
\text { - Due to the limited nature of the terrorist financing offence, it is not } \\
\text { clear how Finland would freeze funds or other assets where the } \\
\text { suspect is an individual terrorist or involved in a terrorist organisation } \\
\text { without a link to a specific terrorist act. } \\
\text { - Finland has issued little specific and clear guidance to financial } \\
\text { institutions and other persons or entities that may be holding } \\
\text { targeted funds in Finland. }\end{array}$ \\
\hline $\begin{array}{l}\text { SR.IV - Suspicious } \\
\text { transaction reporting }\end{array}$ & LC & $\begin{array}{l}\text { - Suspicious transaction reporting is not required re TF unless the } \\
\text { transaction is potentially connected to an act of terrorism. }\end{array}$ \\
\hline $\begin{array}{l}\text { SR.V - International co- } \\
\text { operation }\end{array}$ & LC & $\begin{array}{l}\text { - As dual criminality is required for exercise of coercive measures in } \\
\text { response to a mutual legal assistance request, limitations in the TF } \\
\text { offence limits the extent and effectiveness of mutual legal assistance } \\
\text { provided by Finland where the funds / assets are being collected / } \\
\text { provided for a terrorist organisation or individual terrorist and are not } \\
\text { connected with a terrorist act. } \\
\text { - Effectiveness could not be fully assessed due to limited statistics and } \\
\text { information on practical cases being available. } \\
\text { - The application of dual criminality may create an obstacle to } \\
\text { extradition in cases involving TF where there is no link between the } \\
\text { funding and a specific terrorist act. }\end{array}$ \\
\hline $\begin{array}{l}\mathrm{SR} . \mathrm{VI}-\mathrm{AML} \\
\text { requirements for } \\
\text { money/value transfer } \\
\text { services }\end{array}$ & PC & $\begin{array}{l}\text { - Remittance services are obliged parties under the AML/CFT Act and } \\
\text { are thus subject to the same limitations in the scope of those } \\
\text { obligations as the other obliged parties. } \\
\text { - Remittance services are not required to develop internal controls } \\
\text { (R.15). } \\
\text { - There is a registration system but no supervision of this sector and } \\
\text { therefore no inspections are conducted (R.23) of these businesses. } \\
\text { - Remittances services are subject only to criminal sanctions (R.17). } \\
\text { - Effectiveness of the STR reporting obligation cannot be sully } \\
\text { ascertained as there is no breakdown of STRs submitted by each } \\
\text { money remittance business in Finland (R.16). }\end{array}$ \\
\hline $\begin{array}{l}\text { SR.VII - Wire transfer } \\
\text { rules }\end{array}$ & PC & $\begin{array}{l}\text { - The provisions relating to originator information for wire transfers } \\
\text { within the EU (classified as domestic transfers) is not in compliance } \\
\text { with the FATF requirements under SR.VII'. } \\
\text { - There is no obligation in Finland for institutions to maintain address } \\
\text { details, thus leading to incomplete identification procedures relating } \\
\text { to wire transfers. } \\
\text { - There are no provisions on penalties applicable to infringements of } \\
\text { the wire transfer requirements for the money remittance sector. }\end{array}$ \\
\hline
\end{tabular}

$4 \quad$ The FATF decided at the June 2007 plenary meeting to further consider this subject. 


\begin{tabular}{|c|c|c|}
\hline Recommendations & Rating & Summary of Factors Underlying Rating ${ }^{3}$ \\
\hline $\begin{array}{l}\text { SR.VIII - Non-profit } \\
\text { organisations }\end{array}$ & $\mathrm{PC}$ & $\begin{array}{l}\text { - There has been no review of the NPO sector and no identification of } \\
\text { its vulnerabilities for terrorist financing. } \\
\text { - Information is only obtained on those NPOs which are registered and } \\
\text { an unknown number of NPOs are not registered with authorities. } \\
\text { - No inspections are conducted of the NPO sector. } \\
\text { - The many authorities which have some information on NPOs do not } \\
\text { share this information. } \\
\text { - Authorities do not conduct outreach or provide guidance on terrorist } \\
\text { financing to the NPO sector. } \\
\text { - The system for obtaining information on NPOs is weakened by the } \\
\text { overall lack of measures in Finland to record and obtain information } \\
\text { on beneficial ownership. }\end{array}$ \\
\hline $\begin{array}{l}\text { SR.IX - Cross Border } \\
\text { Declaration \& Disclosure }\end{array}$ & $\mathrm{PC}$ & $\begin{array}{l}\text { - Measures are very new; coming into force almost } 2 \text { months after the } \\
\text { date of this assessment and thus it is too early to ascertain the } \\
\text { effectiveness of this system. } \\
\text { - The EU regulation and relevant national legislation do not cover the } \\
\text { transfer of cash or bearer negotiable instruments between Finland } \\
\text { and another EU member state. }\end{array}$ \\
\hline
\end{tabular}

Table 2: Recommended Action Plan to Improve the AML/CFT System

\begin{tabular}{|c|c|}
\hline AML/CFT SYSTEM & RECOMMENDED ACTION (LISTED IN ORDER OF PRIORITY) \\
\hline \multicolumn{2}{|l|}{ 1. General } \\
\hline \multicolumn{2}{|c|}{ 2. Legal System and Related Institutional Measures } \\
\hline 2.1 Criminalisation of ML (R.1 \& 2) & $\begin{array}{l}\text { - It is recommended that Finland review its } M L \text { offence to cover all } \\
\text { physical elements of the crime, as required in accordance with the } \\
\text { Palermo Convention and introduce the offence of self-laundering. } \\
\text { - The exemption from prosecution for members of a joint household } \\
\text { with the offender should be removed. } \\
\text { - It is recommended that Finland remove the requirement to prove a } \\
\text { connection between the proceeds of crime and a specific } \\
\text { predicate offence. } \\
\text { - The offence of conspiracy should be broadened to apply to the } \\
\text { basic offence of ML, in addition to its application to the offence of } \\
\text { aggravated ML. } \\
\text { The penalties for conspiracy offences should be raised. Similarly, } \\
\text { the penalties for legal persons convicted of ML offences should be } \\
\text { raised. }\end{array}$ \\
\hline 2.2 Criminalisation of TF (SR.II) & $\begin{array}{l}\text { - It is recommended that Finland amend its Penal Code to broaden } \\
\text { the definition of TF to cover financing an individual terrorist or } \\
\text { providing funds to a terrorist organisation where there is no link to } \\
\text { a terrorist act or to terrorist acts that will occur in the future. } \\
\text { - As with the corporate fines available for ML, it is recommended } \\
\text { that Finland increase the penalty available for legal persons } \\
\text { convicted for TF. } \\
\text { - In addition to raising the level of fines which can be levied, terms } \\
\text { of imprisonment for responsible senior executives could be } \\
\text { introduced. }\end{array}$ \\
\hline $\begin{array}{l}2.3 \text { Confiscation, freezing and seizing } \\
\text { of proceeds of crime (R.3) }\end{array}$ & $\begin{array}{l}\text { - It is recommended that Finland conduct a review of its provisional } \\
\text { measures to ensure provisional measures can be used in all ML } \\
\text { cases, including where the proceeds of crime cannot be identified } \\
\text { and when a connection to the offence from which the proceeds } \\
\text { were derived cannot be proven. }\end{array}$ \\
\hline
\end{tabular}




\begin{tabular}{|c|c|}
\hline AML/CFT SYSTEM & RECOMMENDED ACTION (LISTED IN ORDER OF PRIORITY) \\
\hline & $\begin{array}{l}\text { - Similarly, it is recommended that other gaps in the coverage of the } \\
\text { confiscation provisions be closed: it is not possible to confiscate } \\
\text { property of organisations that are found to be primarily criminal in } \\
\text { nature without a specific link to a certain crime; confiscation of } \\
\text { property that has been the target of ML is not possible if the object } \\
\text { is completely mingled with licit assets; it is not possible to void } \\
\text { actions where the persons involved knew or should have known } \\
\text { that as a result of those actions the authorities would be } \\
\text { prejudiced in their ability to recover property subject to } \\
\text { confiscation. } \\
\text { - Provisions on confiscation of the proceeds of crime, and on } \\
\text { confiscation of instrumentalities and other property should be } \\
\text { harmonised to make confiscation of equivalent value possible in } \\
\text { connection with assets that have been the target of ML. } \\
\text { - It is also recommended that the restriction be removed regarding } \\
\text { the confiscation of equivalent value when the property has likely } \\
\text { been destroyed or consumed. }\end{array}$ \\
\hline $\begin{array}{l}\text { 2.4 Freezing of funds used for TF } \\
\text { (SR.III) }\end{array}$ & $\begin{array}{l}\text { - Finland should implement a national mechanism to give effect to } \\
\text { requests for freezing assets and designations from other } \\
\text { jurisdictions and to enable freezing funds of EU internals (citizens } \\
\text { and residents). } \\
\text { - Finland has not established a TF offence which meets all } \\
\text { requirements of Special Recommendation II. It is recommended } \\
\text { that Finland enact measures to allow for freezing funds or other } \\
\text { assets where the suspect is an individual terrorist, belongs to a } \\
\text { terrorist organisation or is otherwise involved in terrorism } \\
\text { unconnected with a terrorist act. } \\
\text { - It is also recommended that a national de-listing process be } \\
\text { established as part of these measures. } \\
\text { Finnish authorities should consider providing clear and practical } \\
\text { guidance to financial institutions and other entities that may hold } \\
\text { terrorist funds concerning their responsibilities under the freezing } \\
\text { regime and provide procedures for authorising access to } \\
\text { funds/assets that are determined to be necessary on humanitarian } \\
\text { grounds in a manner consistent with S/RES/1452(2002) }\end{array}$ \\
\hline $\begin{array}{l}2.5 \text { The Financial Intelligence Unit and } \\
\text { its functions (R.26) }\end{array}$ & $\begin{array}{l}\text { - It is recommended that the MLCH treat its development of a new } \\
\text { database as a priority and that the Finnish Police fully resource } \\
\text { this project. } \\
\text { - It is recommended that the MLCH (in co-operation with other } \\
\text { stakeholders such as the supervisory authorities) pay more } \\
\text { attention to the reasons why only a limited number of institutions } \\
\text { submit STRs and how the reporting behaviour in general can be } \\
\text { improved. } \\
\text { It is recommended that the MLCH improve the guidance provided } \\
\text { to all types of obliged parties and provide feedback to assist with } \\
\text { STR reporting. A list of indicators of suspicious activity or } \\
\text { indicators for different sectors may also assist in this regard. The } \\
\text { current situation where one member of personnel acts as the } \\
\text { central contact point for all obliged parties and is responsible for } \\
\text { training all obliged parties is not realistic. } \\
\text { The MLCH should pay more attention to the development of } \\
\text { trends and typologies related to the STRs received and matters } \\
\text { forwarded to pre-trial investigation. It is recommended that more } \\
\text { experienced members of personnel involved in the day-to-day } \\
\text { work of the MLCH focus on development of typologies, guidance } \\
\text { and support to work with the reporting institutions. Similarly, it is } \\
\text { recommended that the MLCH strengthen mechanisms to obtain } \\
\text { information on the outcomes of matters disseminated and examine } \\
\text { the statistics and feedback from investigators and prosecutors with } \\
\text { a view to improving its understanding of the effectiveness of the }\end{array}$ \\
\hline
\end{tabular}




\begin{tabular}{|c|c|}
\hline AML/CFT SYSTEM & RECOMMENDED ACTION (LISTED IN ORDER OF PRIORITY) \\
\hline & AML/CFT system in Finland. \\
\hline $\begin{array}{l}\text { 2.6 Law enforcement, prosecution and } \\
\text { other competent authorities (R.27 \& } \\
\text { 28) }\end{array}$ & $\begin{array}{l}\text { - It is recommended that Finland develop a more proactive } \\
\text { approach to pursuing ML charges. } \\
\text { - Flexibility for prosecutors to pursue ML and TF charges and the } \\
\text { possibility to allow for prosecution of self-laundering are } \\
\text { recommended. } \\
\text { - There appears not to be a lack of resources with regard to } \\
\text { prosecuting authorities but the resources could be focussed more } \\
\text { on ML and TF matters. } \\
\text { More strategic analysis and the development of typologies, trends } \\
\text { and indicators would be beneficial to support the LEA and } \\
\text { prosecuting authorities in their activities and to draw the attention } \\
\text { of policy makers to problems that currently occur when pursuing } \\
\text { ML and TF. Further awareness raising would complement the } \\
\text { ongoing training initiatives of the MLCH. To assist this, } \\
\text { investigative and prosecutorial authorities should give feedback to } \\
\text { the MLCH on the results of the pre-trial investigations started on } \\
\text { the basis of an STR. } \\
\text { Statistics should be collected on a systematic basis concerning the } \\
\text { ML and TF investigations, prosecutions, convictions and types of } \\
\text { sanctions (criminal and administrative) imposed for ML and TF as } \\
\text { well as on property frozen, seized or confiscated. }\end{array}$ \\
\hline $\begin{array}{l}2.7 \text { Cross Border Declaration \& } \\
\text { Disclosure (SR.IX) }\end{array}$ & $\begin{array}{l}\text { - It is recommended that Finland develop a declaration system } \\
\text { which applies movement of currency between Finland and other } \\
\text { EU member States. } \\
\text { - There is a need for co-ordination between the customs, } \\
\text { immigration and other related authorities in order to fully } \\
\text { implement the EU regulation and national legislation in order to } \\
\text { meet the requirements of Special Recommendation IX. }\end{array}$ \\
\hline \multicolumn{2}{|c|}{ 3. Preventive Measures - Financial Institutions } \\
\hline 3.1 Risk of ML or TF & - \\
\hline $\begin{array}{l}3.2 \text { Customer due diligence, including } \\
\text { enhanced or reduced measures (R.5 } \\
\text { to } 8 \text { ) }\end{array}$ & $\begin{array}{l}\text { Recommendation } 5 \\
\text { - It is recommended that the new AML/CFT Act strengthen the } \\
\text { existing identification requirements by requiring obliged parties to } \\
\text { take and keep a copy of the identification documents presented by } \\
\text { their customer as these records are important, for instance, to } \\
\text { permit the Police to progress investigations even where false } \\
\text { documents are involved. } \\
\text { - Finland should regulate the general obligation to identify the } \\
\text { beneficial owner and verify the information about him/her in legal } \\
\text { persons and arrangements. This is particularly necessary when a } \\
\text { foreign trust operates in Finland. They should include a general } \\
\text { provision about this issue in the act to extent the requirement to all } \\
\text { the situations, not only in case of suspicion, in order to cover all } \\
\text { the obliged parties. } \\
\text { - Finland should implement measures to make sure that the review } \\
\text { of the information of the customers is performed, especially in } \\
\text { cases of enhanced due diligence. } \\
\text { - The monitoring of transactions should be established clearly in the } \\
\text { AML legislation for all obliged parties. } \\
\text { - Finland should implement a domestic list of territories that don't } \\
\text { comply with international standards and should extend enhanced } \\
\text { due diligence to other high risk categories such as for PEPs, } \\
\text { private banking and foreign trusts. } \\
\text { It is recommended that Finland provide an effective simplified }\end{array}$ \\
\hline
\end{tabular}




\begin{tabular}{|c|c|}
\hline AML/CFT SYSTEM & RECOMMENDED ACTION (LISTED IN ORDER OF PRIORITY) \\
\hline & $\begin{array}{l}\text { CDD obligation where appropriate rather than an exemption. } \\
\text { Finland could implement a list of low risk categories where this } \\
\text { "simplified CDD measures" could be applied. } \\
\text { - Finland should consider including an obligation to reject an } \\
\text { existing customer when the CDD obligations can't be fulfilled; and, } \\
\text { in this cases, consider making an STR. } \\
\text { - In the new AML/CFT Act, it is recommended that Finland establish } \\
\text { more clearly the obligation to identify the person who is acting on } \\
\text { behalf the legal person in general terms, not only in case of } \\
\text { enhanced due diligence and ensure this applies to obliged parties, } \\
\text { including insurance, money remitters and foreign exchange } \\
\text { companies. } \\
\text { Recommendation } 6 \\
\text { - Finland should implement legislation which specifically provides } \\
\text { for enhanced due diligence with respect to politically exposed } \\
\text { persons. } \\
\text { Recommendation } 7 \\
\text { Finland should implement legislation which specifically deals with } \\
\text { correspondent banking. } \\
\text { Recommendation } 8 \\
\text { Finland should establish provisions about non face to face } \\
\text { transactions (ongoing due diligence) for all sectors and with } \\
\text { respect to establishing that financial institutions must have policies } \\
\text { to deal with the misuse of technological developments. }\end{array}$ \\
\hline $\begin{array}{l}\text { 3.3 Third parties and introduced } \\
\text { business (R.9) }\end{array}$ & $\begin{array}{l}\text { - The existing provisions could be elaborated with greater specificity } \\
\text { with respect to the outsourcing of customer due diligence } \\
\text { activities, the provision of identification information to the } \\
\text { institution, related controls of the contractual arrangement and } \\
\text { requirements when the third party is located in another country. }\end{array}$ \\
\hline $\begin{array}{l}\text { 3.4 Financial institution secrecy or } \\
\text { confidentiality (R.4) }\end{array}$ & $\begin{array}{l}\text { - Finland should implement provisions which specifically deal with } \\
\text { CDD measures for correspondent banking, including detailing the } \\
\text { information which must be kept by institutions with respect to their } \\
\text { correspondent banking relationships and transactions. }\end{array}$ \\
\hline $\begin{array}{l}\text { 3.5 Record keeping and wire transfer } \\
\text { rules (R.10 \& SR.VII) }\end{array}$ & $\begin{array}{l}\text { Special Recommendation VII } \\
\text { - Finland fully relies on the implementation of the EU regulation on } \\
\text { the payer accompanying transfers of funds as its system of } \\
\text { requirements for originator information in wire transfers. The } \\
\text { regulation classifies wire transfers within the EU as domestic and } \\
\text { therefore only seeks limited originator information on wire transfers } \\
\text { within the European Community. It is recommended that Finland } \\
\text { exercise its option to apply the EU regulation requirements to } \\
\text { transfers within the EU. } \\
\text { Finland should consider introducing a clear mechanism to monitor } \\
\text { compliance of money remitters with the regulation, and establish } \\
\text { the sanctions available for any non-compliance by that sector. }\end{array}$ \\
\hline $\begin{array}{l}\text { 3.6 Monitoring of transactions and } \\
\text { relationships }(\mathrm{R} .11 \& 21)\end{array}$ & $\begin{array}{l}\text { Recommendation } 11 \\
\text { - It is recommended that strengthened provisions in relation to } \\
\text { unusual transactions be included in the new } A M L C F T \text { Act. In } \\
\text { particular, this legislation should clearly require all financial } \\
\text { institutions, not just those supervised by the FSA, to examine the } \\
\text { background and purpose of unusual transactions and should } \\
\text { require obliged parties to keep such findings in writing and } \\
\text { accessible by competent authorities for at least five years. } \\
\text { Recommendation } 21 \\
\text { - It is recommended that strengthened provisions in relation to } \\
\text { jurisdictions which do not or do not sufficiently apply the FATF }\end{array}$ \\
\hline
\end{tabular}




\begin{tabular}{|c|c|}
\hline AML/CFT SYSTEM & RECOMMENDED ACTION (LISTED IN ORDER OF PRIORITY) \\
\hline & $\begin{array}{l}\text { Recommendations be included in the new } A M L / C F T \text { Act or its } \\
\text { regulations. In particular, this legislation should clearly require all } \\
\text { financial institutions to document their findings when enquiring into } \\
\text { these transactions and to keep such findings accessible for } \\
\text { competent authorities or auditors. } \\
\text { - In addition, it is recommended that Finland ensure that a system is } \\
\text { in place to advise all obliged parties of the countries and } \\
\text { jurisdictions which do not or insufficiently apply the FATF } \\
\text { Recommendations so the obliged parties may effectively comply } \\
\text { with s.11a of the } A M L / C F T \text { Act and s.10 of the AML/CFT Decree. } \\
\text { - Finland may also want to consider creating additional types of } \\
\text { counter-measures which could be applied by it to countries or } \\
\text { territories which do not or insufficiently apply the FATF } \\
\text { Recommendations. }\end{array}$ \\
\hline $\begin{array}{l}\text { 3.7 Suspicious transaction reports and } \\
\text { other reporting (R.13-14, 19, } 25 \text { \& } \\
\text { SR.IV) }\end{array}$ & 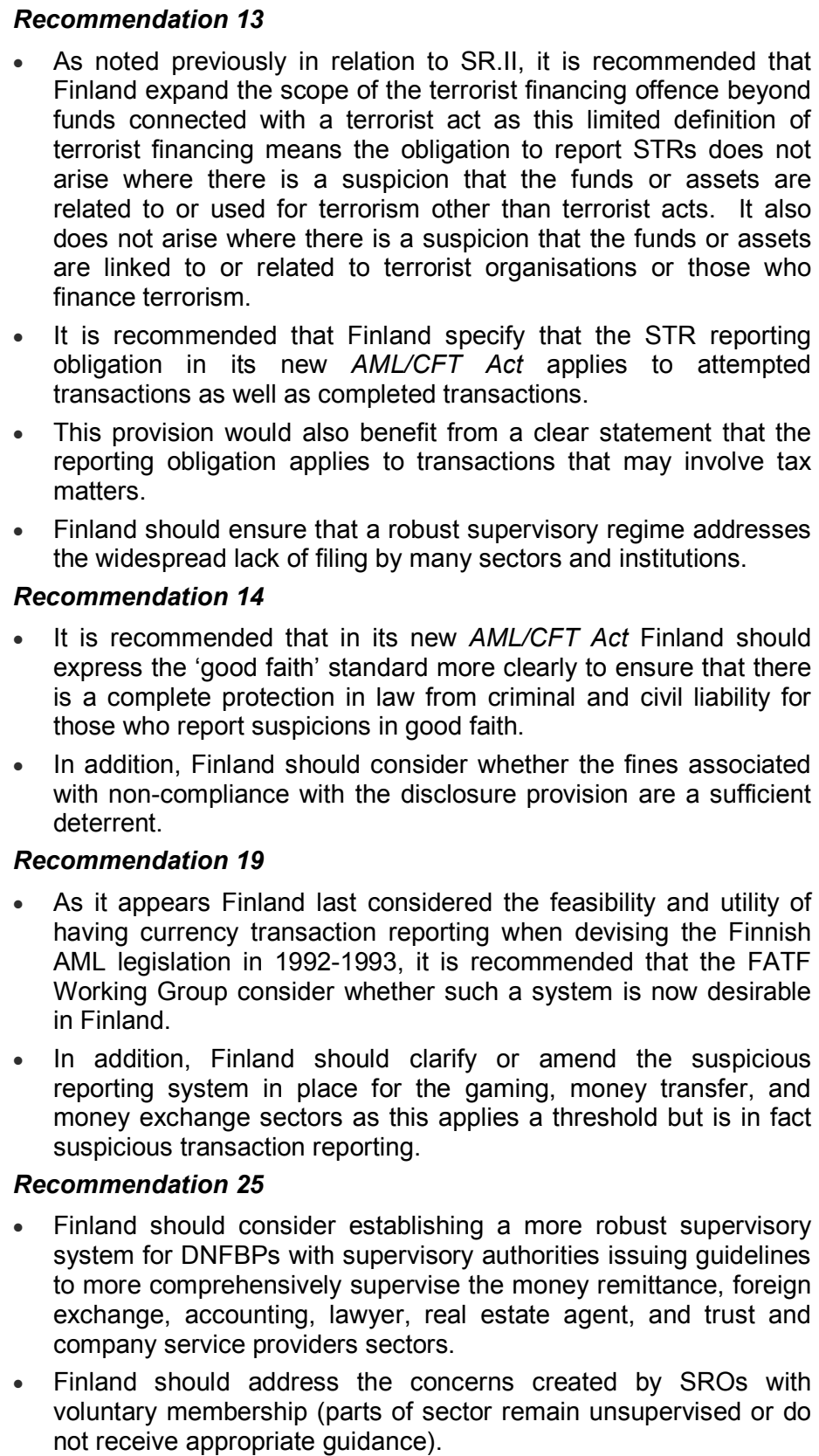 \\
\hline
\end{tabular}




\begin{tabular}{|c|c|}
\hline AML/CFT SYSTEM & RECOMMENDED ACTION (LISTED IN ORDER OF PRIORITY) \\
\hline & $\begin{array}{l}\text { Special Recommendation IV } \\
\text { - Finland's limited definition of terrorist financing should be } \\
\text { expanded to include transactions not connected to a terrorist act } \\
\text { (See SR II), thereby requiring suspicious transaction reporting for } \\
\text { funds linked or related to terrorism, terrorist acts, or terrorist } \\
\text { organisations. } \\
\text { This obligation should include an explicit provision requiring } \\
\text { reporting for attempted transactions, as well as transactions that } \\
\text { may involve tax matters in connection with terrorist financing. }\end{array}$ \\
\hline $\begin{array}{l}3.8 \text { Internal controls, compliance, audit } \\
\text { and foreign branches (R.15 \& 22) }\end{array}$ & $\begin{array}{l}\text { Recommendation } 15 \\
\text { - The money remittance and foreign exchange sectors should have } \\
\text { explicit rules that require internal controls, compliance officers, and } \\
\text { training to ensure compliance with the identification, reporting, and } \\
\text { customer due diligence requirements of the AML/CFT Act. } \\
\text { - Sectors not supervised by the FSA need explicit binding } \\
\text { requirements to have an independent audit function for AML } \\
\text { compliance and to ensure appropriate screening procedures are in } \\
\text { place when hiring employees. } \\
\text { Recommendation } 22 \\
\text { Finland should consider implementing standards for non-FSA } \\
\text { supervised institutions similar to s.1(5) of FSA standard } 2.4 \text {, } \\
\text { Customer Identification and Customer Due Diligence - Prevention } \\
\text { of Money Laundering, Terrorism Financing and Market Abuse. } \\
\text { Finland should require, not simply allow, all institutions to inform } \\
\text { their supervisory authority when a foreign branch or subsidiary is } \\
\text { prohibited by the local rules from observing AML/CFT measures. }\end{array}$ \\
\hline 3.9 Shell banks (R.18) & $\begin{array}{l}\text { - Finland should consider expressly prohibiting the operation of shell } \\
\text { banks, rather than relying on the licensing system for financial } \\
\text { institutions to uncover shell bank operations. } \\
\text { - The FSA should clarify explicitly in its CDD and Customer ID } \\
\text { standards that institutions cannot maintain correspondent banking } \\
\text { relationships with shell banks. } \\
\text { - More generally, such requirements should be binding for other } \\
\text { non-bank sectors, including the insurance, money remitter, and } \\
\text { foreign exchange sectors. } \\
\text { - Finland should require all institutions to perform due diligence to } \\
\text { satisfy themselves that their respondent institutions do not allow } \\
\text { indirect access to their accounts by shell banks. }\end{array}$ \\
\hline $\begin{array}{l}3.10 \text { The supervisory and oversight } \\
\text { system - competent authorities and } \\
\text { SROs. Role, functions, duties and } \\
\text { powers (including sanctions) (R.23, } \\
29,17 \text { \& 25) }\end{array}$ & $\begin{array}{l}\text { Recommendation } 17 \\
\text { - Finland should consider adopting additional binding requirements } \\
\text { for the money remittance and foreign exchange sectors beyond } \\
\text { the } A M L / C F T \text { Act, and appointing a supervisory authority to } \\
\text { monitor these sectors' compliance with all AML/CFT provisions } \\
\text { and sanction non-compliance. } \\
\text { - It is recommended that Finland clearly clarifying its sanction } \\
\text { provisions to note their applicability to directors and senior } \\
\text { management within obliged parties. } \\
\text { - It is recommended that Finland clearly review and raise the } \\
\text { strength of the sanctions available to supervisors for non- } \\
\text { compliance with AML/CFT obligations and that supervisory } \\
\text { authorities in fact apply sanctions where appropriate. } \\
\text { Recommendation } 23 \\
\text { - It is recommended that Finland clearly clarifying its sanction } \\
\text { provisions to note their applicability to directors and senior } \\
\text { management within obliged parties. } \\
\text { It is recommended that there be specific requirements for all }\end{array}$ \\
\hline
\end{tabular}




\begin{tabular}{|c|c|}
\hline AML/CFT SYSTEM & RECOMMENDED ACTION (LISTED IN ORDER OF PRIORITY) \\
\hline & 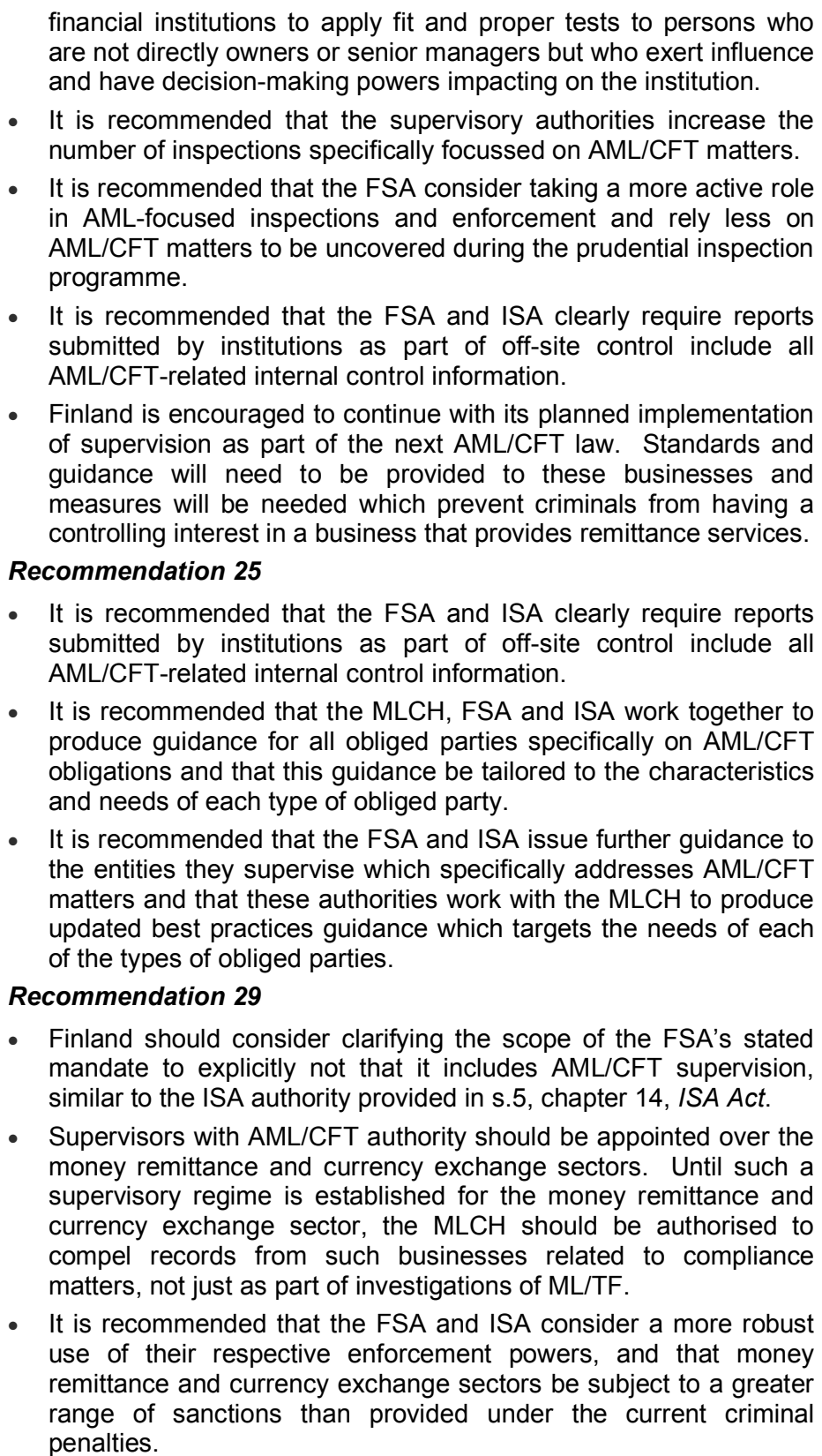 \\
\hline $\begin{array}{l}\text { 3.11 Money value transfer services } \\
\text { (SR.VI) }\end{array}$ & $\begin{array}{l}\text { - Finland should address the concerns raised previously in } \\
\text { Recommendations } 13,14,15,21,22 \text {, and } 23 \text { with respect to the } \\
\text { remittance sector as well as other obliged parties. } \\
\text { - Finland is encouraged to establish an AML/CFT supervisor for the } \\
\text { sector, with sufficient powers and sanctions available to it to } \\
\text { ensure compliance by these businesses with the full range of } \\
\text { AML/CFT obligations. It is recommended that this supervisor work } \\
\text { with the MLCH to ensure an effective STR reporting system is put } \\
\text { in place for the sector and is implemented throughout the sector. }\end{array}$ \\
\hline \multicolumn{2}{|c|}{ 4. Preventive Measures - Non-Financial Businesses and Professions } \\
\hline 4.1 Customer due diligence and & $\begin{array}{l}\text { - The same recommendations made previously for action by Finland } \\
\text { with respect to Recommendations } 5 \text { to } 8 \text { are also applicable for } \\
\text { the DNFBP sector. }\end{array}$ \\
\hline
\end{tabular}




\begin{tabular}{|c|c|}
\hline AML/CFT SYSTEM & RECOMMENDED ACTION (LISTED IN ORDER OF PRIORITY) \\
\hline record-keeping (R.12) & $\begin{array}{l}\text { - Finland is encouraged to apply the new } A M L / C F T \text { Act to trust and } \\
\text { company service providers. } \\
\text { - The same recommendations for action by Finland expressed } \\
\text { previously with respect to Recommendations } 10 \text { and } 11 \text { are } \\
\text { applicable for the DNFBP sector. } \\
\text { - It is recommended that a targeted programme be put in place to } \\
\text { increase implementation of the FATF standards by DNFBPs and } \\
\text { that active AML/CFT supervision of these business and } \\
\text { professions be conducted. } \\
\text { It is further recommended that a review be conducted of the } \\
\text { obligations in the gaming sector, including a review of } \\
\text { requirements for non face-to-face activities. } \\
\text { - Finland should ensure that AML/CFT obligations are applied } \\
\text { completely and consistently, including in the Âland Islands. }\end{array}$ \\
\hline $\begin{array}{l}\text { 4.2 Suspicious transaction reporting } \\
\text { (R.16) }\end{array}$ & $\begin{array}{l}\text { - It is recommended that Finland ensure its new AML/CFT } \\
\text { legislation is widened in scope to capture trust and company } \\
\text { service providers as obliged parties. } \\
\text { - Finland's limited definition of the financing of terrorism (see SRIly) } \\
\text { should be expanded to include the reporting of transactions not } \\
\text { directly linked to a terrorist act. } \\
\text { - Finland should explicitly clarify that both transactions related to tax } \\
\text { matters and any attempted transactions that otherwise meet the } \\
\text { suspicious transaction reporting criteria should be reported. } \\
\text { - It is strongly recommended that in the new AML/CFT legislation } \\
\text { Finland implement supervision and inspection of DNFBPs' } \\
\text { compliance with the obligation to report STRs to address the } \\
\text { widespread lack of filing by many sectors and institutions. This } \\
\text { supervision could draw on the expertise of existing supervisors in } \\
\text { terms of provision of standards for all DNFBPs similar to those for } \\
\text { FSA-supervised entities requiring internal controls, fully } \\
\text { empowered compliance officers, independent audit, } \\
\text { comprehensive employee training, and employee screening } \\
\text { procedures to manage AML/CFT risks. } \\
\text { It is recommended that Finland ensure that all DNFBPs are } \\
\text { notified by an appropriate government authority of high-risk } \\
\text { jurisdictions or other areas of concern. } \\
\text { Finland should address the jurisdictional disagreements between } \\
\text { the Finnish government and the government of the Âland Islands } \\
\text { with respect to gaming and should ensure that AML/CFT } \\
\text { obligations and robust controls and supervision are applied } \\
\text { consistently across the entire gaming sector. }\end{array}$ \\
\hline $\begin{array}{l}4.3 \text { Regulation, supervision and } \\
\text { monitoring (R.24-25) }\end{array}$ & $\begin{array}{l}\text { Recommendation } 24 \\
\text { - The relevant supervisory authorities should consider issuing more } \\
\text { exhaustive binding rules for casinos to supplement the minimum } \\
\text { requirements of the } A M L / C F T \text { Act. } \\
\text { - Finland should clarify to the gaming sector the difference between } \\
\text { threshold-based reporting and true suspicious transaction } \\
\text { reporting as defined by the FATF, as well as clarify that existing } \\
\text { sanctions can be imposed against the directors or senior } \\
\text { management of a casino. } \\
\text { - In addition, Finland should empower the appropriate supervisory } \\
\text { authorities with other powers of enforcement in addition to the } \\
\text { criminal sanctions for failure to comply with the AML/CFT Act. } \\
\text { - Finland must address the jurisdictional concerns that are } \\
\text { precluding the equitable and consistent enforcement of AML/CFT } \\
\text { measures for the casino sector in the Âland Islands. } \\
\text { It is recommended that Finland evaluate the vulnerabilities in the } \\
\text { system of voluntary membership in SROs for the legal and }\end{array}$ \\
\hline
\end{tabular}




\begin{tabular}{|c|c|}
\hline AML/CFT SYSTEM & RECOMMENDED ACTION (LISTED IN ORDER OF PRIORITY) \\
\hline & $\begin{array}{l}\text { accounting sectors, recognising the importance of ensuring } \\
\text { compliance by all businesses within a certain sector. } \\
\text { In addition to subjecting the trust and company service provider } \\
\text { sector to AML requirements, Finland should establish a relevant } \\
\text { and adequately empowered supervisor for both the trust and } \\
\text { company service providers and the dealers in previous metals and } \\
\text { stones. } \\
\text { Recommendation } 25 \\
\text { - Finland should consider establishing a more robust system of } \\
\text { provision of guidance and feedback to DNFBPs with information } \\
\text { tailored for the nature of their activities. It is recommended that in } \\
\text { doing so, Finnish authorities address the need to provide guidance } \\
\text { to businesses which are not members of SROs as well as those } \\
\text { which are members. }\end{array}$ \\
\hline $\begin{array}{l}\text { 4.4 Other non-financial businesses } \\
\text { and professions (R.20) }\end{array}$ & $\begin{array}{l}\text { - Implementation of a risk-based approach is one of the expected } \\
\text { features of the new AML/CFT legislation. It is recommended that } \\
\text { Finnish authorities conduct a comprehensive assessment to } \\
\text { identify AML/CFT risks. }\end{array}$ \\
\hline
\end{tabular}

\section{Legal Persons and Arrangements \& Non-Profit Organisations}

5.1 Legal Persons - Access to beneficial ownership and control information (R.33)
- It is recommended that legal persons be required to keep and make available to authorities information on beneficial ownership and control. This irequirement may be incorporated in the Companies Act, Trade Register Act and related legislation so as to strengthen the Trade Register system and availability of information on beneficial ownership and control.

- It is recommended that Finland consider implementing a programme of monitoring or supervision by the $\mathrm{PRH}$ of the full range of obligations of legal persons to hold and submit updated information for the trade registers.

5.2 Legal Arrangements - Access to beneficial ownership and control information (R.34)

- While the Finnish legal system does not allow for the creation of trusts, and the legal concept of trust does not exist in Finnish law, it may nevertheless be useful for Finland to consider examining issues with respect to trusts and provide information to raise awareness of Finnish financial institutions of these types of legal arrangements.

5.3 Non-profit organisations (SR.VIII)

- It is recommended that Finland conduct a review of its non-profit sector, including reviews of TF risks, and a review of the legislation in place to ensure the transparency of and appropriate conduct within the sector. It should use this information to fully implement a registration requirement for all bodies operating in the sector and to begin a program of outreach and awareness-raising with the NPOs with a view to strengthening their resistance to terrorist financing abuse.

- Finland should implement measures to effectively supervise the non-profit sector, including implementation of an effective range of sanctions for inappropriate conduct. In support of this supervision system, exchanges of information and co-ordination between authorities should be improved in order to increase the volume of useful information about NPOs.

\section{National and International Co-operation}

6.1 National co-operation and coordination (R.31)
- Is it recommended that the national FATF Working Group treat this need for information collection and information sharing and as a priority issue so that an overall picture of the effectiveness of Finland's AML/CFT system can be developed.

- In addition, as AML/CFT supervisors for the remittance and currency exchange sectors are established, it is recommended 


\begin{tabular}{|c|c|}
\hline AML/CFT SYSTEM & RECOMMENDED ACTION (LISTED IN ORDER OF PRIORITY) \\
\hline & $\begin{array}{l}\text { that Finland ensure that they are sufficiently able to co-operate } \\
\text { and exchange information with other supervisory and enforcement } \\
\text { authorities. }\end{array}$ \\
\hline $\begin{array}{l}\text { 6.2 The Conventions and UN Special } \\
\text { Resolutions (R.35 \& SR.I) }\end{array}$ & $\begin{array}{l}\text { - As noted previously, it is recommended that Finland amend its ML } \\
\text { offence as it does not currently implement all physical elements of } \\
\text { the ML offence required by the Vienna and Palermo Conventions. } \\
\text { - In addition it is recommended that the ancillary offence of } \\
\text { conspiracy to conduct ML be created and the conspiracy to } \\
\text { conduct aggravated ML widened to cover conspiracy to conduct all } \\
\text { aspects of the aggravated ML offence. } \\
\text { - In order to fully implement the Vienna and Palermo conventions, it } \\
\text { is further recommended that Finland criminalise self-laundering } \\
\text { and ML by members of a joint household with the offender who } \\
\text { use or consume the proceeds of crime for ordinary needs in the } \\
\text { joint household. } \\
\text { Further conduct of a review of the adequacy of penalties is } \\
\text { recommended, particularly penalties for conspiracy to commit } \\
\text { aggravated money laundering and for participation in a criminal } \\
\text { organisation. } \\
\text { Finland should enact stronger measures for customer identification } \\
\text { so as to more fully implement article } 18 \text { of the Terrorist Financing } \\
\text { Convention and should include an explicit provision in its Penal } \\
\text { Code clarifying that criminal acts under the scope of the Terrorist } \\
\text { Financing Convention are under no circumstances justifiable by } \\
\text { considerations of political, philosophical, ideological, racial, ethnic, } \\
\text { religious or other similar nature. } \\
\text { With respect to full implementation of S/RES/1267(1999) and its } \\
\text { successor resolutions and S/RES/1373(2001), it is recommended } \\
\text { that Finland implement a national mechanism to give effect to } \\
\text { requests for freezing assets and designations from other } \\
\text { jurisdictions, a de-listing process, and procedures for accessing } \\
\text { funds/assets that are frozen and that are determined to be } \\
\text { necessary on humanitarian grounds. }\end{array}$ \\
\hline $\begin{array}{l}\text { 6.3 Mutual Legal Assistance (R.36-38 } \\
\text { \& SR.V) }\end{array}$ & $\begin{array}{l}\text { - In order to ensure that coercive measure could consistently be } \\
\text { applied for all requesting countries, it is recommended that Finland } \\
\text { criminalise (1) conspiracy to conduct ML, (2) conspiracy to } \\
\text { conduct all aspects of aggravated ML, ( } 3 \text { ) self-laundering, and (4) } \\
\text { collecting or providing funds/assets where these are for a terrorist } \\
\text { organisation or individual terrorist without a connection to a } \\
\text { terrorist act. } \\
\text { - Finland should consider establishing an asset confiscation fund } \\
\text { into which all or a portion of confiscated property would be } \\
\text { deposited for use by law enforcement, health, education or other } \\
\text { appropriate programs. }\end{array}$ \\
\hline 6.4 Extradition (R.39, 37 \& SR.V) & $\begin{array}{l}\text { - It is recommended that Finland amend its Penal Code to broaden } \\
\text { the definition of TF to cover financing an individual terrorist or } \\
\text { providing funds to a terrorist organisation where there is no link to } \\
\text { a specific terrorist act. } \\
\text { - It is also recommended that the offence of conspiracy be } \\
\text { broadened to apply to basic ML and all forms of aggravated ML }\end{array}$ \\
\hline $\begin{array}{l}\text { 6.5 Other Forms of Co-operation } \\
\text { (R.40 \& SR.V) }\end{array}$ & - \\
\hline \multicolumn{2}{|l|}{ 7. Other Issues } \\
\hline 7.1 Resources and statistics (R. 30 \& & $\begin{array}{l}\text { - Finland should keep (or provide if they are kept) statistics } \\
\text { regarding requests received or made by the various supervisory } \\
\text { authorities. In addition, statistics collection with respect to training }\end{array}$ \\
\hline
\end{tabular}




\begin{tabular}{|c|c|}
\hline AML/CFT SYSTEM & RECOMMENDED ACTION (LISTED IN ORDER OF PRIORITY) \\
\hline 32) & $\begin{array}{l}\text { and inspections conducted could be improved. } \\
\text { - Authorities may benefit from collecting and analysing more } \\
\text { detailed statistics on the declaration system. } \\
\text { It is recommended that Finland keep a complete set of statistics } \\
\text { pertaining to mutual legal assistance, thus enabling it to better } \\
\text { track the requests it receives and makes and enabling it to ensure } \\
\text { that these are being handled in a timely way. In particular, it would } \\
\text { be useful to have statistics on the nature of requests, whether they } \\
\text { were granted or refused, what crimes they related to, and the } \\
\text { length of time taken to respond to the request. } \\
\text { Finland should collect and maintain more comprehensive statistics } \\
\text { on extraditions from Finland, the duration for the requests to be } \\
\text { actioned and the specific offences they relate to. } \\
\text { Statistics are not available which would allow for sufficient } \\
\text { evaluation of Finland's investment in international co-operation. } \\
\text { The MLCH and the FSA maintain some statistics concerning } \\
\text { international co-operation, however these are not sufficient to fully } \\
\text { assess the effectiveness of the system. It is recommended that } \\
\text { Finnish authorities collect, maintain and share statistics } \\
\text { concerning international co-operation involving the FIU, } \\
\text { enforcement and supervisory authorities. }\end{array}$ \\
\hline $\begin{array}{l}7.2 \text { Other relevant AML/CFT } \\
\text { measures or issues }\end{array}$ & - \\
\hline $\begin{array}{l}7.3 \text { General framework - structural } \\
\text { issues }\end{array}$ & - \\
\hline
\end{tabular}

